\title{
Avoidance in Processing English Non-restrictive Relative Clauses in Thai EFL Learners' Interlanguage
}

\author{
Sonthaya Rattanasak ${ }^{1} \&$ Supakorn Phoocharoensil ${ }^{1}$ \\ ${ }^{1}$ Language Institute of Thammasat University, Thammasat University, Bangkok, Thailand \\ Correspondence: Sonthaya Rattanasak \& Supakorn Phoocharoensil, Language Institute of Thammasat University, \\ Phrachan Road Phranakorn, Bangkok 10200, Thailand. E-mail: reconfirm_22@hotmail.com
}

Received: June 12, 2014 Accepted: July 1, 2014 Online Published: August 28, 2014

doi:10.5539/ass.v10n17p265

URL: http://dx.doi.org/10.5539/ass.v10n17p265

\begin{abstract}
This paper examined the acquisition of English non-restrictive relative clauses (NRCs) by L1 Thai learners, focusing on avoidance strategies applied in the learners' interlanguage. The theoretical frameworks of the Noun Phrase Accessibility Hierarchy (NPAH) and the Perceptual Difficulty Hypothesis (PDH) were the main hypotheses predicting avoidance behavior employed by the learners. The research participants were 80 Thai EFL high school students of high and low proficiency levels. The data were elicited through a sentence combination task and a Thai-English translation task. The findings, overall, suggested that Thai EFL learners, by and large, avoided using the more marked NRC types in the NPAH. The learners' avoidance was evident in the tasks from the shifting of more marked types to less marked ones. The findings also showed that the more advanced learners tended to employ more avoidance behavior with regard to the NPAH, which may be attributed to their greater exposure to the L2 rules and more knowledge of the differences between the L1 and L2 structures; this resulted in the use of alternative ways to complete the given tasks more easily. The center-embedded NRCs, more precisely, were found to be problematic for learners, which supports the prediction of the PDH that clauses embedded after the subject positions may interrupt the processing of a complex structure of RCs. The learners, therefore, avoided center embedding and changed it to right embedding with little awareness of the ungrammaticality of the NRC sentences.
\end{abstract}

Keywords: avoidance strategy, non-restrictive relative clause, Noun Phrase Accessibility Hierarchy, Perceptual Difficulty Hypothesis

\section{Introduction}

English relative clauses (ERCs) appear to pose a major obstacle hindering second language (L2) learners from achieving L2 competence. Over the decades, many second language acquisition (SLA) researchers have focused on ERC acquisition, and several theoretical frameworks have been proposed to account for learners' acquisition of ERCs.

The classic hypotheses devoted to ERC acquisition investigations are, namely, the Noun Phrase Accessibility Hierarchy (NPAH), posited by Keenan and Comrie (1977), and the Perceptual Difficulty Hypothesis (PDH), formulated by Kuno (1974). A considerable number of SLA researchers have put substantial effort into investigating how L2 learners of different mother tongue (L1) backgrounds acquire ERCs (e.g., Abdolmanafi \& Rezaee, 2012; Chang, 2010; Chou, 2006; Gass, 1979, 1980; Izumi, 2003; Man, 2007; Phoocharoensil, 2010; Schumann, 1978; Zhu, 2014). However, the studies on which these theories were based mainly dealt with how L2 learners acquire English restrictive relative clauses (RRCs); in contrast, non-restrictive relative clauses (NRCs) have been little discussed especially in a Thai EFL context.

As seen in previous studies (e.g., Gass, 1980; Phoocharoensil, 2010; Schachter, 1974; Yip \& Matthews, 1991; Zhu, 2014), avoidance strategy seems to account for learners' acquisition of ERCs. Moreover, avoidance seems to play a crucial role as learners are trying to master the complex structure of L2. In particular, it may no longer be true to conclude that learners are competent in processing RCs, as the findings show a high degree of accuracy with regard to final production. It was pointed out by Schachter (1974) that learners whose L1 RC structures differed greatly from those in L2 were inclined to produce fewer RCs, preventing error analysis from detecting the actual learning strategies applied during the acquisition of ERCs. 
On these grounds, the present investigation, therefore, aimed to examine the avoidance strategies used in the acquisition of English NRCs by Thai L1 learners in an attempt to answer the following research question.

\subsection{Research question}

How do Thai EFL learners of high and low proficiency levels avoid English non-restrictive relative clauses?

\subsection{Hypothesis}

Thai EFL learners of different proficiency levels will adopt different sorts of avoidance strategies, which can be predicted by the degree of universal markedness of the NPAH and the difficulty occasioned by the short-term temporary memory that influences the processing of NRCs as suggested by the PDH.

Since this study placed its emphasis on avoidance strategies based on the two theoretical frameworks of the Noun Phrase Accessibility Hierarchy and the Perceptual Difficulty Hypothesis, this section concerns the pertinent literature on the frameworks and avoidance strategy in L2 learning in relation to Thai EFL learners' acquisition of English non-restrictive relative clauses.

\subsection{English Relative Clauses}

According to Cowan (2008), English restrictive relative clauses (RRCs), as the name implies, are used to restrict the essential information of modified noun phrases. In contrast, non-restrictive relative clauses (NRCs) are used to add information about the noun phrases they modify (Loock, 2010). These two types of ERCs are usually syntactically, semantically and phonologically different. Non-restrictive relative clauses, which are sometimes called non-defining, non-identifying, or appositive relative clauses, are referred to as a type of relative clause whose function is to simply add information to modified noun phrases or the whole preceding clauses. Structurally, NRCs can be strictly introduced by only wh-relative pronouns; namely, who, whom, whose, and which, and are always set off from the matrix clause by the use of commas as well as pauses and lower pitch in speech. NRCs are used to provide additional information, which is unimportant with respect to determining the identity of the modified noun phrases or the entire proposition in the matrix clauses (Celce-Murcia \& Larsen-Freeman, 1999, pp. 591-594; Loock, 2010, pp. 15-16). The following sentence, i.e., (1), is an example of a NRC in English, where the head noun Naomi is a definite proper noun.

This is Naomi, who sells the tickets.

(Swan, 2005, p. 480)

Unlike Thai RCs, English NRCs are distinguishable from RRCs in different aspects. One of these ways to be taken into consideration is the head noun phrase or antecedent. English relative clauses are postnominal modifiers (Cowan, 2008, p. 420), which are similar to those in Thai. However, there are some elements regarding the antecedents that are used differently in English RRCs and NRCs, which can be problematic for L2 learners. Since proper nouns denote specific information - that is, the head noun itself is already and obviously identified or definite, it is unnecessary that the reference be restricted (Cowan, 2008, p. 438; Quirk, Greenbaum, Leech, \& Svartvik, 1985, p. 1241). Therefore, proper nouns can be modified by a NRC as shown in (2), where the NRC who lives in the U.K. modifies the proper noun John.

John, who lives in the U.K., is getting married in June.

John who lives in the U.K. is getting married in June.

(adapted from Lock, 1996, p. 256)

However, Letourneau (2001, pp. 324-325) indicates that this rule can be applied to most NRCs except for the case in which two people have the same name as in (3). The noun John is then treated as a common noun rather than a proper noun with definiteness, because the sentence implies that there are two or more people whose names are alike; therefore, the clause can function as a restrictive relative clause (Quirk et al., 1985, p. 1241). Letourneau (2001, pp. 324-326) further proposed that generic common nouns and definite common nouns can also be modified by a NRC.

Professors, who like poetry, are well paid.

Professors who like poetry are well paid.

(adapted Thomas \& Kintgen, 1974, p. 198)

The above sentences are structurally different in that (4) has commas around the relative clause who like poetry, while (5) does not. The significance is that plural common nouns with no determiners may take the generic reference's role; therefore, it is meant to be unrestricted, because the head noun refers to all members under that 
generic common noun. Hence, both examples shown in (4-5) are possible in English; however, (4) is treated as a NRC, whereas (5) is a RRC (Loock, 2010, p. 13). Moreover, definite common nouns which are introduced by the can be modified by either a NRC or a RRC. The following sentences illustrate their functions when the antecedents are definite common nouns.

The students, who took first place in the debate tournament, are from Brown University.

The students who took first place in the debate tournament are from Brown University.

(Letourneau, 2001, p. 326)

These two functions differ depending upon the previous sentences, specifically, whether the definite common nouns have already been mentioned before. If that is the case, it is usually modified by a NRC, as in (6). Nonetheless, definite common nouns can also be modified by a RRC, as illustrated in (7), in order to limit the implication to only that group of students (Letourneau, 2001, p. 326). As far as the head noun phrase functions are concerned, it is worth noting that those distinctions can be far beyond learners' capability to distinguish the two types of ERCs. However, in the present study, only NRCs modifying proper head noun phrases were taken into consideration with the justification that the proper noun phrases seem to be the most obvious type that can be modified by a NRC.

\subsection{Thai Relative Clauses}

According to Suktrakul (1975), Thai RCs are postnominal modifiers, which are similar to their English counterparts. Suktrakul (1975) suggested that Thai RCs could have four grammatical functions in modification, i.e., 1) subject, 2) direct object, 3) indirect object, and 4) object of preposition. In Sornhiran (1978), it was pointed out that Thai relative pronouns can function in three types, i.e., 1) subject, 2) direct object, and 3) indirect object. In addition, with reference to the findings in Sornhiran (1978) and Suktrakul (1975), the distinction of syntactic structures between RRCs and NRCs in Thai seems to remain in dispute. However, Suktrakul (1975) proposed that Thai RRCs could be distinguished from Thai NRCs by the use of a noun classifier, as shown in (8), while (9), without a noun classifier, is regarded as a NRC.

$\begin{array}{rllllll}\text { RRC chéd tó? tua } & \text { thîi jùu mum-hôon dûajná } \\ \text { clean table (classifier) } & \text { which be corner-room please }\end{array}$

'Clean the table which is in the corner of the room, please.'

(Suktrakul, 1975, p. 107)

$\begin{array}{llllll}\text { NRC chéd tó? } & \text { thîi } & \text { jùu } & \text { mum-hôon dûajná } \\ & \text { clean table } & \text { which be } & \text { corner-room please }\end{array}$

'Clean the table, which is in the corner of the room, please.'

(Suktrakul, 1975, p. 107)

\subsubsection{Grammatical Functions of Thai Relative Pronouns}

In Thai, there are three grammatical functions of relative pronouns as follows: 1) subject, 2) direct object, and 3) indirect object (Sornhiran, 1978). The other three functions, as suggested by the NPAH, i.e., objects of prepositions, genitive, and objects of comparisons, seem to be non-existent in Thai (Gass, 1979).

1) subject (SU)

$\begin{array}{lllllll}\text { kasàt an } & \text { sonkhroэyrâat } & \text { manaan } & \text { yîisip } & \text { pii } & \text { sînphráchon } & \text { mîawaan } \\ \text { king who } & \text { rule } & \text { for } & \text { twenty } & \text { year } & \text { die } & \text { yesterday }\end{array}$

'The king, who had ruled the country for twenty years, passed away yesterday.'

(Sornhiran, 1978, p. 27)

2) direct object (DO)

$$
\begin{aligned}
& \text { yay?uân thîi thəə chôวp... } \\
& \text { the plump girl whom she like... } \\
& \text { the plump girl, whom she likes,...' }
\end{aligned}
$$

3) indirect object (IO) 


$\begin{array}{llllll}\text { dèk thîi } & \text { kháw hây } & \text { kâw?îi } & \text { pay... } \\ \text { child whom } & \text { he } & \text { give } & \text { chair } & \text { go... }\end{array}$

'the child, whom he gave the chair,...'

(adapted from Sornhiran, 1978, p. 175)

The relative pronoun grammatical function distinction between Thai, L1, and English, L2 could play a significant role in learner's avoidance behaviour. According to Odlin (1989, pp. 36-37), cross-linguistic differences can result in: 1) underproduction, 2) overproduction, 3) production errors, and 4) misinterpretation. Avoidance behavior can be seen when underproduction is detected. If L2 learners are faced with a particular structure in L2 that differs greatly from that in their L1, they are consequently inclined to avoid using such a structure (Odlin, 1989, p. 37).

\subsection{The Noun Phrase Accessibility Hierarchy (NPAH)}

One of the most extensively applied hypotheses on the study of ERC acquisition is the Noun Phrase Accessibility Hierarchy, as proposed by Keenan and Comrie (1977). This hypothesis is aimed at investigating the language universals of the relativizability of different grammatical functions in different positions of the head noun phrases that are relativized in sentences containing relative clauses.

$$
\mathrm{SU}>\mathrm{DO}>\mathrm{IO}>\mathrm{OPREP}>\mathrm{GEN}>\mathrm{OCOMP}^{1}
$$

(Keenan \& Comrie, 1977, p. 66)

Below is an illustration of each grammatical function of relative clauses in the NPAH.

SU George Smith, who won the Booker prize, is my lifelong friend.

DO George Smith, whom we met, won the Booker prize.

IO George Smith, to whom I introduced you, won the Booker prize.

OPREP George Smith, with whom we had dinner, won the Booker prize.

GEN George Smith, whose husband we met, won the Booker prize.

OCOMP $^{2} \quad$ George Smith, whom I have written fewer books than, has won the Booker prize.

(adapted from Ellis, 1997, p. 64)

As shown above, the most accessible type, which is also considered the least marked type in the NPAH, is presumably the subject (SU); meanwhile, the type that seems to be far beyond learners' acquisition is the object of comparison (OCOMP). Direct object (DO) is predicted to be less marked than indirect object (IO), followed by object of preposition (OPREP) or sometimes called object of oblique (OBL), according to the relativizability in the NPAH. Genitive RC (GEN), of which many past investigations (e.g., Chou, 2006; Gass, 1979, 1980) have revealed comparatively mixed results, is ranked as the second most marked type in the hierarchy (Ellis, 1997, pp. 63-65). Furthermore, it is probable that if a L1 allows any of the RC types in the hierarchy in that language itself, there is a possibility that the other type(s) on the left to the end of the hierarchy will also exist in that L1 (Gass, Behney \& Plonsky, 2013, pp. 229-230; Keenan \& Comrie, 1977, pp. 67-68). For instance, the RC type IO is allowed in Thai RCs (Sornhiran, 1978). Thus, it may be generally predicted that Thai relative clauses should include DO and SU as well. In addition, Keenan and Comrie (1977) suggested that if a language itself has RCs, it is generally true that the subject (SU) modification is an easier type to acquire than the others in the hierarchy (Keenan \& Comrie, 1977). As far as the degree of difficulty in relativizability is concerned, learners' avoidance could be attributed to the accessibility predicted by the NPAH. A higher degree of difficulty in relativization in different grammatical functions of relative pronouns in NRCs might also play a vital role in Thai EFL learners' acquisition of English NRCs.

\subsection{The Perceptual Difficulty Hypothesis (PDH)}

The Perceptual Difficulty Hypothesis (PDH) is viewed as a concept for illustrating how delimitation in human temporary memory influences one's processing of sentences (Kuno, 1974). According to this notion, Kuno (1974) suggested that a sentence consisting of a center-embedded relative clause, which is inserted into the matrix clause and usually interrupts the process of the sentence, would presumably be more difficult to acquire than a sentence with a right-embedded relative clause. Below are samples of relative clause sentences with different embedding types.

OS: The little girl is looking for her cat, Bob, which ran away. 
OO: The boys are reading Harry Potter, which they borrowed from the library.

SS: The Mona Lisa picture, which won the prize, is hanging on the wall.

SO: The Nike jacket, which I found on the bus, belongs to Susie.

(Adapted from Schumann, 1978, p. 118)

To be more precise, OS and OO types are seen as far easier than SS and SO ones (i.e., the first letter O represents the grammatical function of head noun phrases of the matrix clause, whereas the second letter refers to the grammatical function of relative pronouns of the relative clause). Subject is abbreviated as $\mathrm{S}$, and $\mathrm{O}$ represents Object. According to the PDH, OS and OO types are perceptually easier than SS and SO types. In (19), in the main clause, $B o b$ is obviously seen to have a function as an object in the main clause and the relative clause which ran away is attached to the last word of the main clause, modifying the preceding head noun Bob. This right-embedded NRC serves to give more details about its subject Bob. Like (19), the relative clause which they borrowed from the library in (20) is also right-embedded. Even so, the function of the RC pronoun in this NRC is to refer to its object Harry Potter. By contrast, the other two sentences (21) and (22) are center-embedded. That is, the NRCs here are inserted in the middle of the matrix clauses, functioning to describe The Mona Lisa picture in (21) and The Nike jacket in (22), which are the subjects of the main clauses. These two sentences differ in terms of the functions of the relative pronouns in the NRCs. The RC pronoun which in (21) functions as a subject of the NRC itself, which won the prize, while which in (22) functions as an object in the NRC, which I found on the bus. Sentences with center-embedded relative clauses (i.e., clauses that are embedded in the matrix sentence in the subject position) as in (21) and (22) are considered perceptually more difficult to process than those with right-embedded relative clauses (i.e., clauses that are embedded in the matrix sentence in the object position) as shown in (19) and (20). It should be noted here that the prediction of the PDH is different from that of the NPAH in that the PDH has no concentration on any relative clause type. As clearly seen, the PDH is concerned with the position the RCs are placed in the sentence.

\subsection{Avoidance}

According to Ellis (1997), Gass et al. (2013), and Odlin (1989), avoidance may be the result of L1 transfer, which is one of the five psycholinguistic processes suggested by Selinker (1972) that is related to the systematic linguistic knowledge of a L2 learner who is attempting production of a target language norm. Avoidance can be seen when learners try to comprehend L2 complex structures. Kleinmann (1977) pointed out that avoidance tends to occur as a result of L1 and L2 differences. Gass et al., (2013) supported this, stating that learners may be influenced by their native language and be selective in terms of which structures to produce and which not to. Avoidance is one of the learning strategies that L2 learners seem to employ when they are faced with difficulty in learning a L2 (Ellis, 1994). Odlin (1989) also pointed out that L2 learners may try to avoid structures in the target language that are very different from those in their mother tongue. As revealed by several past studies, avoidance could be ascribed to many factors, two of which are lack of L2 competence and transfer of L1 knowledge (Gass et al., 2013, p. 141). Studies shedding light on avoidance strategy employment in ERC acquisition include, for instance, Chou (2006), Gass (1980), Phoocharoensil (2010), Schachter (1974), Yip and Matthews (1991), and Zhu (2014). A well-known piece of evidence of avoidance can be found in a very early study by Schachter (1974), who discovered learners' errors were not always observed by considering only the final outputs. The learners' natural language found in her study suggested the potential of avoiding the use of RCs as learners of L1 Chinese and Japanese produced fewer relative clauses due to the differences in L1 and L2. In addition, Gass (1980), who included Thai EFL learners in her study, found that the learners from different L1 backgrounds as well as Thai avoided using relative clauses in different ways. In a similar vein, Chou (2006) conducted research on relative clause acquisition in Taiwanese EFL learners and found avoidance strategies were employed in object positions in a higher number when compared to subject ones in the acquisition of relative clauses, and center embedding was avoided more than the right embedding type. Additionally, Phoocharoensil (2010) investigated Thai EFL learners' natural language from a translation task and a speaking task, reporting that more marked types, GEN and OCOMP, were avoided. Yip and Matthews (1991) also found in their analysis of written work produced by English major students that learners were capable of producing RCs on subjects, as predicted by the NPAH. Nevertheless, avoidance of the other RC types was noticed, implying that the learners were aware of the structures but were unable to use them in their spontaneous writing. In a recent study of syntactic transfer in RC learning of L1 Chinese learners, Zhu (2014) found strong support for the prediction of the PDH, specifically RCs with center embedding. It was revealed that the wrong position of RCs, which signified learners' avoidance, may be ascribed mainly to the difficulty as proposed in the PDH that center embedding was one of the major factors preventing L2 learners from fully understanding ERCs. 


\section{Method}

\subsection{Participants}

The research participants were 80 grade 11 high school Thai EFL students of different proficiency levels, i.e., high and low. They were equally divided into two groups according to their language proficiency as determined by their GPA for English subjects that they had studied in the past three semesters. Learners who were bilingual or had been in an English speaking country for more than three consecutive months were excluded, since their linguistic competence might not be useful for the present investigation and may not clearly represent Thai EFL learners' interlanguage in general.

\subsection{Research Instruments}

Two data collection techniques, i.e., a sentence combination task and a Thai-English translation task, were used to elicit productive interlanguage data in each type of NRCs in connection with the NPAH and the PDH. In addition, the learners were allowed to consult a dictionary to help them overcome difficulty concerning unfamiliar vocabulary.

\subsection{Data Analysis}

The analysis of this investigation was based on the attempts to produce NRCs, which failed to conform to the target syntactic constructions of each NRC type in the hierarchy. The second observation followed the evidence from Gass (1980). The category of avoidance strategy found in her study revealed that learners switched the order of the two sentences in order to embed the sentence, which was intended as the matrix clause. Those non target-like NRC sentences were taken into consideration to reveal what type of NRCs was deliberately and alternatively relied on by the learners as a result of their avoidance behavior, regardless of whether they were grammatically produced after the alterations of the target constructions. In the present investigation, it should be noted from this explanation that it is not necessary that avoidance result in the production of errors; rather, it reveals learners' interlanguage competence in using ERCs. An error analysis was then performed and the results were discussed to reveal the learners' avoidance behaviour influenced by the two hypotheses. Frequency and percentage of the avoidance strategies used in both tasks were quantitatively and descriptively reported. Errors not related to NRC formation were excluded. For instance, errors concerning verb conjugation, tenses or English articles were not considered. The punctuation use of commas was excluded from the investigation of avoidance because the data as such were unsuitable for the hypotheses of the NPAH and the PDH.

\section{Results and Discussion}

In the present research, it was evident that there were two major types of avoidance strategies employed by Thai EFL learners in the high and low proficiency groups.

Table 1. Frequency and percentage of avoidance in the sentence combination task

\begin{tabular}{|c|c|c|c|c|c|c|c|c|c|c|c|c|c|}
\hline \multirow{2}{*}{ Avoidance } & \multicolumn{5}{|c|}{ High group } & \multirow{2}{*}{ Total } & \multirow{2}{*}{ Avoidance } & \multicolumn{5}{|c|}{ Low group } & \multirow{2}{*}{ Total } \\
\hline & $\mathrm{SU}$ & DO & IO & OPREP & GEN & & & SU & DO & IO & OPREP & GEN & \\
\hline NPAH & - & 1 & 2 & - & 1 & 4 & NPAH & - & 1 & 2 & 3 & 1 & 7 \\
\hline$\%$ & - & 25 & 50 & - & 25 & 100 & $\%$ & - & 14.29 & 28.56 & 42.86 & 14.29 & 100 \\
\hline PDH & & 4 & - & 2 & 1 & 7 & PDH & 5 & 8 & - & 2 & - & 15 \\
\hline$\%$ & & 57.14 & - & 28.57 & 14.29 & 100 & $\%$ & 33.33 & 53.33 & - & 13.34 & - & 100 \\
\hline
\end{tabular}

Table 2. Frequency and percentage of avoidance in the translation task

\begin{tabular}{|c|c|c|c|c|c|c|c|c|c|c|c|c|c|}
\hline \multirow{2}{*}{ Avoidance } & \multicolumn{5}{|c|}{ High group } & \multirow{2}{*}{ Total } & \multirow{2}{*}{ Avoidance } & \multicolumn{5}{|c|}{ Low group } & \multirow{2}{*}{ Total } \\
\hline & SU & DO & IO & OPREP & GEN & & & SU & DO & IO & OPREP & GEN & \\
\hline NPAH & - & - & - & 15 & - & 15 & NPAH & - & - & - & 11 & - & 11 \\
\hline$\%$ & - & - & - & 100 & - & 100 & $\%$ & - & - & - & 100 & - & 100 \\
\hline PDH & - & - & - & - & - & - & $\mathrm{PDH}$ & 3 & - & 1 & - & - & 4 \\
\hline$\%$ & - & - & - & - & - & - & $\%$ & 75 & - & 25 & - & - & 100 \\
\hline
\end{tabular}




\subsection{Avoidance Strategy}

\subsubsection{Avoidance Strategy: NPAH}

Avoidance of more marked types in the NPAH

(A) I know Pat.

(B) The host is offering drinks to Pat.

Expected combination: I know Pat, whom the host is offering drinks to. (IO)

Avoidance: The host is offering drinks to Pat whom I know. (DO)

Avoidance as shown above was mainly seen in more marked types, for instance, OPREP and IO, i.e., the learners altered the expected NRC type to the less difficult, less marked construction, DO, as predicted by the degree of markedness in the hierarchy. The learners' attempts to produce DO, which they probably felt more comfortable to employ, were found to violate the instruction asking them to begin with the sentence (A) as a matrix clause and embed the sentence (B) as a subordinate clause to form a NRC sentence. In regard to avoidance in the NPAH, in the translation task OPREP was especially avoided in a relatively high number by the two groups: 15 tokens in the high group and 11 tokens in the low group, respectively. In contrast, in the sentence combination task, avoidance was found in several more marked NRC types. In the high group, IO (50\%), GEN $(25 \%)$, DO $(25 \%)$ were avoided, respectively, whereas the low group seemed to avoid producing OPREP (42.86\%), IO (28.56\%), GEN (14.29\%) and DO (14.29\%) in the given order.

The occurrence as such may possibly stem from the impact of the degree of markedness in the accessibility hierarchy or the impartial mastery of the sentence constructions that make the learners deliberately choose not to produce the target form (Gass, 1980). L2 learners often depend on avoidance strategy when faced with difficulty in processing a complex structure (Ellis, 1994; Kleinmann, 1977). The results from both tasks showed that avoidance seemed to occur in more marked positions of the NPAH, which lent support to past studies on avoidance investigations e.g., Chou (2006), Gass (1980), Man (2007), Phoocharoensil (2010), and Phoocharoensil and Simargool (2010), and supported the hypothesis of this study. In Phoocharoensil and Simargool (2010), the learners' problems were investigated with 90 Thai EFL undergraduates of different proficiency levels through an essay writing task and a translation task. The findings on avoidance behavior seemed to be correlated closely with the present study's results. Thai EFL learners had more likelihood of avoiding the use of more marked RCs in their writing. More precisely, it was found that OPREP and GEN were avoided in a higher number when compared to SU in the writing task. The results were supported by the findings of the translation task as well. The learners were found to use more marked types less accurately in the task. As regards SU, the least marked type in the NPAH, the findings from Man's study (2007) on ERC acquisition corroborated the present research results in that object positions, e.g., DO and OPREP, seemed to be avoided in a higher number than SU and were produced less accurately, while SU was the most correctly produced and avoidance seemed not to occur for this RC type (Yip \& Matthews, 1991). The results found in avoidance behavior in the NPAH confirmed the prediction of the NPAH (Keenan \& Comrie, 1977) as it was indicated that the learners' performance after the employment of avoidance strategies showed a lower marked NRC type corroborating the NPAH (Chou, 2006). The findings shown above were in line with the results from Chou (2006) and Gass (1980). Switching the order of the two sentences in order to embed the sentence, which was intended as the matrix, was found in the sentence combining task in their investigations as well. The learners, particularly Chinese and Arabic, adopted avoidance strategy and produced the RC in a less marked type in place of the more marked ones (Chou, 2006; Gass, 1980). Learners' violation of the instructions of the task revealed that they seemed to deliberately choose the easier type to process. The learners' avoidance, as the data indicated, usually resulted in an easier NRC sentence. This evidently showed that avoidance is at play when Thai EFL learners are trying to communicate in L2 English.

\subsubsection{Avoidance Strategy: PDH}

Not only did the Thai EFL learners encounter difficulty processing center-embedded NRCs, but they were also found to avoid using center-embedded NRCs by shifting to the right-embedded ones, which was found in a high number, especially in the sentence combination task.

Avoidance of center-embedded positions (PDH)

(A) Laura is my close friend.

(B) I like her very much.

Expected combination: Laura, whom I like very much, is my close friend. 
Avoidance: Laura is my close friend, whom I like very much.

Table 3. Examples of the learners' avoidance in the sentence combination task

\begin{tabular}{|c|c|}
\hline Avoidance type & Example NRC sentences of avoidance from the learners \\
\hline $\begin{array}{l}\text { Avoidance of } \\
\text { more marked } \\
\text { types (NPAH) }\end{array}$ & $\begin{array}{l}\text { 1. A) I walked home with Olivia. } \\
\text { B) I bought some candies for Olivia. } \\
\text { Target NRC: I walked home with Olivia, whom I bought some candies for. } \\
\text { Avoidance: I bought some candies for Olivia who walked home with me. (OPREP) to (SU) } \\
\text { 2. A) The Samsung refrigerator is too old. } \\
\text { B) You keep fresh food in it. } \\
\text { Target NRC: The Samsung refrigerator, which you keep fresh food in, is too old. } \\
\text { Avoidance: You keep fresh food in the Samsung refrigerator which is too old. (OPREP) to (SU) } \\
\text { 3. A) I know Pat. } \\
\text { B) The host is offering drinks to Pat. } \\
\text { Target NRC: I know Pat, whom the host is offering drinks to. } \\
\text { Avoidance: The host is offering drinks to Pat whom I know. (IO) to (DO) } \\
\text { 4. A) Laura is my close friend. } \\
\text { B) I like her very much. } \\
\text { Target NRC: Laura, whom I like very much, is my close friend. } \\
\text { Avoidance: I like Laura who is my close friend very much. (DO) to (SU) } \\
\text { 5. A) This is Eric. } \\
\text { B) His house is next to my house. } \\
\text { Target NRC: This is Eric, whose house is next to my house. } \\
\text { Avoidance: This is Eric who has house next to my house. (GEN) to (SU) }\end{array}$ \\
\hline $\begin{array}{l}\text { Avoidance of } \\
\text { center-embedded } \\
\text { position (PDH) }\end{array}$ & $\begin{array}{l}\text { 1. A) Laura is my close friend. } \\
\text { B) I like her very much. } \\
\text { Target NRC: Laura, whom I like very much, is my close friend. } \\
\text { Avoidance: Laura is my close friend whom I like very much. (DO) } \\
\text { 2. A) Matt will buy a new boat next week. } \\
\text { B) Matt is my best friend. } \\
\text { Target NRC: Matt, who is my best friend, will buy a new boat next week. } \\
\text { Avoidance: Matt will buy a new boat next week who is my best friend. (SU) } \\
\text { Avoidance: Matt is my best friend who will buy a new boat next week. (SU) } \\
\text { 3. A) The Samsung refrigerator is too old. } \\
\text { B) You keep fresh food in it. } \\
\text { Target NRC: The Samsung refrigerator, which you keep fresh food in, is too old. } \\
\text { Avoidance: The Samsung refrigerator is too old which you keep fresh food in it. (OPREP) } \\
\text { 4. A) Kit Kat chocolate is very sweet. } \\
\text { B) Its packet is red. } \\
\text { Target NRC: Kit Kat chocolate, whose packet is red, is very sweet. } \\
\text { Avoidance: Kit Kat chocolate is very sweet whose packet is red. (GEN) }\end{array}$ \\
\hline
\end{tabular}


According to the prediction of the PDH, it could be expected that center-embedded position RCs have a high possibility to be perceptually more difficult for learners to process than right-embedded position RCs.

Avoidance in the PDH dealt with different positioning of center embedding and right embedding. In the translation task, only the less-proficient learners were found to avoid using center-embedded NRC types, i.e., SU (75\%) and IO (25\%) sequentially. However, avoidance was noticed in more marked NRC types in the sentence combination task. That is, DO (57.14\%), OPREP (28.57\%), and GEN (14.29\%) with center-embedded NRCs were avoided by the more advanced learners. By contrast, the learners with less proficiency tended to avoid center-embedded NRC types DO (53.33\%), SU (33.33\%) and OPREP (13.34\%), respectively. The findings lent support to Phoocharoensil (2009) in suggesting that Thai EFL learners tend to avoid using center-embedded ERCs in favour of right-embedded ERCs, as predicted by their complexity and the difficulty in the PDH (Kuno, 1974). In Chou's study (2006), the learners were likely to avoid the center-embedded type and tended to rely more on the right-embedded one. Moreover, Zhu (2014) also held this tendency to be true in her study of syntactic transfer in RC learning of L1 Chinese college students. She found that the learners attempted to avoid producing center-embedded RCs and substituted the use by embedding the $\mathrm{RC}$ at the end of the main clause, which often resulted in ungrammatical RC sentences and may be attributed to the complexity and the difficulty of the structure as posited by the PDH. It is worth noting that learners tried to achieve linguistic competence by completing the given task using their L2 communicative learning strategy, and retaining the general idea of the message, although, to a certain extent, the production contradicted the target construction, the meaning and the explicit instructions and could be considered as errors. Learners' avoidance in both task types can be seen in Table 3 and Table 4.

Table 4. Examples of the learners' avoidance in the translation task

\begin{tabular}{ll}
\hline \multicolumn{1}{c}{ Avoidance type } & \multicolumn{1}{c}{ Example NRC sentences of avoidance from the learners } \\
\hline Avoidance of more & 1. กล้องโซนี่ที่พวกเราถ่ายรูปเป็นประจำราคาถูกมาก \\
marked types & Target NRC: The Sony camera, which we usually take a photo with, is very cheap. \\
(NPAH) & Avoidance: The Sony camera, which we always use, is very cheap. (OPREP) to (DO) \\
& 2. ลิซ่ารู้จัก ไมค์คนที่เธอพูดถึง \\
& Target NRC: Lisa knows Mike, whom you talk about. \\
& Avoidance: Lisa know Mike whom you mention. (OPREP) to (DO) \\
& Avoidance: Lisa knows Mike who is mentioned by her. (OPREP) to (SU) \\
\hline Avoidance of & 1. นิโคล แจ็คสันที่เป็นนักร้องจะมที่นี่เดือนหน้า \\
center-embedding & Target NRC: Nicole Jackson, who is a singer, will be here next month. \\
& Avoidance: Nicole Jackson is a singer who is going to come here next month. (SU) \\
& 2. เจมส์คนที่ฉันให้ลูกอมน่ารักมาก \\
& Target NRC: James, whom I gave a candy to, is very cute. \\
& Avoidance: Jame is a pretty boy whom I gave a candy to. (IO) \\
\hline
\end{tabular}

\section{Conclusion}

The present investigation placed its emphasis on examining avoidance as reflected in the learners' learning strategy. Thai EFL learners deliberately chose to produce a less marked and complex clause while avoiding the target syntactic constructions of the NRCs. Accordingly, this paper is possibly able to explain Thai EFL learners' avoidance strategies used in their interlanguage in the NRC acquisition. It was revealed that the NPAH and the PDH can be in large measure responsible for Thai EFL learners' avoidance behavior in the acquisition of NRCs as predicted by the degree of markedness in the NPAH, and the difficulty resulting from intervention in the processing of center-embedded NRCs may occasion the avoidance behavior.

The major source of avoidance found in the present study seems to be the exposure to, and the complexity of, the structures in L2. As regards the NPAH, the learners, as the findings from both tasks indicated, were inclined to avoid more marked NRCs in the hierarchy, i.e., OPREP ( 29 tokens), IO (4 tokens), GEN (2 tokens) and DO (2 tokens), respectively. The learners deliberately produced sentences using the less marked NRCs instead of the 
target structures. This implied that the learners probably know that the more marked structures, e.g., OPREP, exist, but they may be unfamiliar with them or not confident about producing them. The phenomenon may be ascribed to the complexity of the constructions, thus leading the learners to shift such structures to a less marked one, e.g., DO, which they may find less problematic to perform. They switched the order of the sentences, and made changes to lexical items and syntactic structures so as to avoid using the more marked types. Learners' avoidance by modifying the sentence from a more marked NRC to a less marked NRC may be attributed mainly to their exposure to $\mathrm{L} 2$ rules and the complexity of the structures as posited by the NPAH.

Likewise, avoidance behavior found in the learners' processing of NRCs with center embedding indicates the learners' strategies in formulating a NRC. The learners found center-embedded NRCs more complicated to process than the right-embedded ones. As shown in the data from both tasks, the learners clearly avoided using center-embedded NRCs in object positions in a high number, i.e., DO (12 tokens), SU ( 8 tokens), OPREP (4 tokens), IO (1 token) and GEN (1 token) sequentially, by changing from the targeted center-embedded NRCs to the right-embedded ones with little awareness of the ungrammaticality of the sentences, resulting in sentences that were inappropriate. It is evident in the findings that not only did they avoid the center-embedded NRCs, but they were also found to resort to the right-embedded counterparts to complete the sentences, which are considered easier to process according to the prediction of the PDH. As for learners' proficiency as a variable predicting the use of avoidance strategies, learners with less proficiency employed more avoidance than the high proficiency ones, which could be explained by the difficulty occasioned by the complexity of relative clauses in $\mathrm{L} 2$ as predicted by the $\mathrm{PDH}$.

To summarize, the learners seemed to avoid using the more marked NRC types and showed their L2 communicative strategy by completing the task with an easier NRC type. This could be explained by the learners' exposure to L2 rules and the complexity of the L2 relative clause structures as posited by the NPAH and the $\mathrm{PDH}$. The extent of avoidance is particularly significant for complex target relative clause constructions by less-proficient learners; however, more advanced learners may also employ avoidance strategies when faced with the complexity of relative clause structures of the $\mathrm{L} 2$.

\section{Acknowledgment}

The authors are grateful to the Language Institute of Thammasat University, Thailand, for the financial support granted for this research.

\section{References}

Abdolmanafi, S. J., \& Rezaee, A. (2012). The difficulty hierarchy in the acquisition of English relative clauses by Persian learners. International Journal of English and Education, 1(2), 170-179.

Celce-Murcia, M., \& Larsen-Freeman, D. (1999). The grammar book: An ESL/EFL teacher's course (2nd ed.). Singapore: Heinle \& Heinle Publishers.

Chang, C. (2010). The use of relative clauses in Taiwanese EFL graduate students' proposal writing. MA thesis, National Yunlin University of Science \& Technology, Department of Applied Foreign Languages.

Chou, Y. H. (2006). Acquisition of English relative clauses by Taiwan EFL college students. MA thesis, National Sun Yet-Sen University.

Cowan, R. (2008). The teacher's grammar of English: A course book and reference guide. Cambridge: Cambridge University Press.

Ellis, R. (1994). The study of second language acquisition. Oxford: Oxford University Press.

Ellis, R. (1997). Second language acquisition. Oxford: Oxford University Press.

Gass, M. (1979). Language transfer and universal grammatical relations. Language Learning, 29, 327-344. http://dx.doi.org/10.1111/j.1467-1770.1979.tb01073.x

Gass, S. (1980). An investigation of syntactic transfer in adult second language learners. In R. Scarcella, \& S. Krashen (Eds.), Research in second language acquisition (pp. 132-141). Rowley, MA: Newbury House.

Gass, S., Behney, J., \& Plonsky, L. (2013). Second language acquisition: An introductory course (4th ed.). New York: Routledge.

Izumi, S. (2003). Processing difficulty in comprehension and production of relative clauses by learners of English as a second language. Language Learning, 53(2), 285-323. http://dx.doi.org/10.1111/1467-9922. 00218

Keenan, E., \& Comrie, B. (1977). Noun phrase accessibility and universal grammar. Linguistic Inquiry, 8, 63-99. 
http://dx.doi.org/10.2307/413321

Kleinmann, H.H. (1977). Avoidance behavior in adult second language acquisition. Language Learning, 27(1), 93-107. http://dx.doi.org/10.1111/j.1467-1770.1977.tb00294.x

Kuno, S. (1974). The position of relative clauses and conjunctions. Linguistic Inquiry, 5, 117-136.

Letourneau, M. S. (2001). English grammar. Fort Worth, TX: Harcourt College Publishers.

Lock, G. (1996). Functional English grammar. Cambridge: Cambridge University Press.

Loock, R. (2010). Appositive relative clauses in English: Discourse functions and competing structures. Amsterdam: John Benjamins. http://dx.doi.org/10.1075/sidag.22

Man, L. J. (2007). An empirical study of Chinese EFL learners' behavior on English relative clauses: Bridging typology and SLA. PhD. dissertation, Shanghai Jiaotong University.

Odlin, T. (1989). Language transfer: Cross-linguistic influence in language learning. Cambridge: Cambridge University Press. http://dx.doi.org/10.1017/CBO9781139524537

Pavesi, M. (1986). Markedness, discoursal modes, and relative clause formation in a formal and an informal context. Studies in Second Language Acquisition, 8, 38-55. http://dx.doi.org/10.1017/S0272263100005829

Phoocharoensil, S. (2009). A study of English relative clauses in the interlanguage of Thai EFL learners. PhD. Dissertation, Chulalongkorn University.

Phoocharoensil, S. (2010). Language universals and learning strategies in L2 relative clause acquisition. The International Journal of Learning, 17(2), 95-108.

Phoocharoensil, S., \& Simargool, N. (2010). English relativization and learners' problems. Pan-Pacific Association of Applied Linguistics, 14(1), 109-129.

Quirk, R., Greenbaum, S., Leech, G., \& Svartvik, J. (1985). A comprehensive grammar of English language. New York: Longman.

Schachter, J. (1974). An error in error analysis. In L. Ortega (Ed.), Second language acquisition: Critical concepts in linguistics (pp. 41-48). New York: Routledge.

Schumann, J. (1978). The acquisition of English relative clauses by second language learners. In R. Scarcella, \& S. Krashen (Eds.), Research in second language acquisition: Selected papers from the Los Angeles Second Language Research Forum (pp. 118-131). Rowley, MA: Newbury House.

Selinker, L. (1972). Interlanguage. International Review of Applied Linguistics, 10, 209-232. http://dx.doi.org/10. 1515/iral.1972.10.1-4.209

Sornhiran, P. (1978). A transformational study of relative clauses in Thai (PhD Dissertation). University of Texas at Austin.

Suktrakul, S. (1975). Contrastive analysis of relative clauses in Thai-English. Doctoral dissertation, UMI Dissertation Information Service, Ann Arbor, Mich.

Swan, M. (2005). Practical English usage. Oxford: Oxford University Press.

Thomas, O. P., \& Kintgen, E. R. (1974). Transformational grammar and the teacher of English: Theory and practice (2nd ed.). USA: Holt, Rinehart and Winston, Inc.

Yip, V., \& Matthews, S. (1991). Relative complexity: Beyond avoidance. Chinese University of Hong Kong Papers in Linguistics, 3, 112-124.

Zhu, L. (2014). A study of syntactic transfer in relative clause learning of Chinese college English majors. Theory and Practice in Language Studies, 4(3), 613-617. http://dx.doi.org/10.4304/tpls.4.3.613-617

\section{Notes}

Note 1. The scale illustrates the least accessible type of RCs to the most accessible one. SU $=$ subject, DO = direct object, $\mathrm{IO}=$ indirect object, $\mathrm{OBL}=$ oblique, $\mathrm{GEN}=$ genitive, $\mathrm{OCOMP}=$ object of comparative.

Note 2. OCOMP was excluded from the present investigation because its infrequent use among L2 learners (Pavesi, 1986), particularly in Thai EFL learners (Phoocharoensil, 2009).

Note 3. Example sentences of avoidance shown in Table $3 \& 4$ were drawn from the learners' interlanguage in using NRCs in accordance with the NPAH and the PDH. Errors irrelevant to avoidance in producing NRCs, e.g., 
a lack of commas and use of resumptive pronouns, were left undescribed since the data as such were unsuitable for the purpose of the present research.

\section{Appendix A}

\section{Sentence Combination Task}

Directions: Use the words whose, that, whom, who, and which or no relative pronoun to combine each pair of sentences into one correct sentence with appropriate punctuation. Please keep the meaning unchanged and always begin a new sentence with sentence A.
1. A) Laura is my close friend.
B) I like her very much.

Laura, whom I like very much, is my close friend.
2. A) This is Eric.
B) His house is next to my house.

This is Eric, whose house is next to my house.
3. A) I want to watch Titanic.
B) Titanic is a romantic movie.

I want to watch Titanic, which is a romantic movie.
4. A) Matt will buy a new boat next week.
B) Matt is my best friend.

Matt, who is my best friend, will buy a new boat next week.
5. A) The Samsung refrigerator is too old.
B) You keep fresh food in it.

The Samsung refrigerator, which you keep fresh food in, is too old.

The Samsung refrigerator, in which you keep fresh food, is too old.
6. A) That is Barbara.
B) We gave a ticket to Barbara.

That is Barbara, whom we gave a ticket to.

That is Barbara, to whom we gave a ticket.
7. A) I know Pat.
B) The host is offering drinks to Pat.

I know Pat, whom the host is offering drinks to.

I know Pat, to whom the host is offering drinks.
8. A) I walked home with Olivia.
B) I bought some candies for Olivia.

I walked home with Olivia, whom I bought some candies for.

I walked home with Olivia, for whom I bought some candies.
9. A) Kit Kat chocolate is very sweet.
B) Its packet is red.

Kit Kat chocolate, whose packet is red, is very sweet.
10. A) My sister is cleaning the new iPad.
B) I bought it from Hong Kong.
My sister is cleaning the new iPad, which I bought from Hong Kong.

\section{Appendix B}

Translation Task

Direction: Translate the sentences that are written in Thai into English. You may consult a dictionary for unfamiliar words.

\section{1. แมรี่ชอบดูโดเรม่อนซึ่งเป็นการ์ตูนญี่ปุ่น}

Mary likes to watch Doraemon, which is a Japanese cartoon.

\section{2. นิโคล แจ็คสันที่เป็นนักร้องจะมาที่นี่เดือนหน้า}

Nicole Jackson, who is a singer, will be here next month.

\section{3. ซูซานกำลังอ่านแฮรี่พอตเตอร์ที่ฉันซื้อมาเมื่อสัปดาห์ที่แล้ว}

Susan is reading Harry Potter, which I bought last week.

\section{4. เจมส์คนที่ฉันให้ลูกอมน่ารักมาก}


James, whom I gave a candy to, is very cute.

James, to whom I gave a candy, is very cute.

\section{5. กล้องโซนี่ที่พวกเราถ่ายรูปเป็นประจำราคาถูกมาก}

The Sony camera, which we usually take a photo with, is very cheap.

The Sony camera, with which we usually take a photo, is very cheap.

6. ฉันรู้จักเมย์คนที่เธอส่งของขวัญไปให้

I know May, whom you sent a gift to.

I know May, to whom you sent a gift.

\section{7. ลิซ่ารู้จักไมค์คนที่เธอพูดถึง}

Lisa knows Mike, whom you talk about.

Lisa knows Mike, about whom you talk.

\section{8. โจที่มีพี่ชายเป็นหมอ ไม่มาทำงานวันนี้}

Joe, whose brother is a doctor, doesn't come to work today.

\section{9. จิมมี่คนที่คุณชอบมีแฟนแล้ว}

Jimmy, whom you like, has a girlfriend.

10. ฉันทำงานกับหมอสุดาที่มีพี่สาวเป็นพยาบาล

I work with Dr. Suda, whose sister is a nurse.

\section{Copyrights}

Copyright for this article is retained by the author(s), with first publication rights granted to the journal.

This is an open-access article distributed under the terms and conditions of the Creative Commons Attribution license (http://creativecommons.org/licenses/by/3.0/). 